Int.J. Hum. Soc. Dev. Res.

ISSN (P):2521-1439; ISSN (E):2523-4331

Volume 3, № 2, 2019. 41-49

DOI:10.30546/2523-4331.2019.3.2.41

\title{
USING GROUP WORK IN TEACHING WRITING SKILL
}

\section{KHALID}

Universitas Muslim Nusantara AW Medan, Indonesia

\section{(C) The Author(s) 2019}

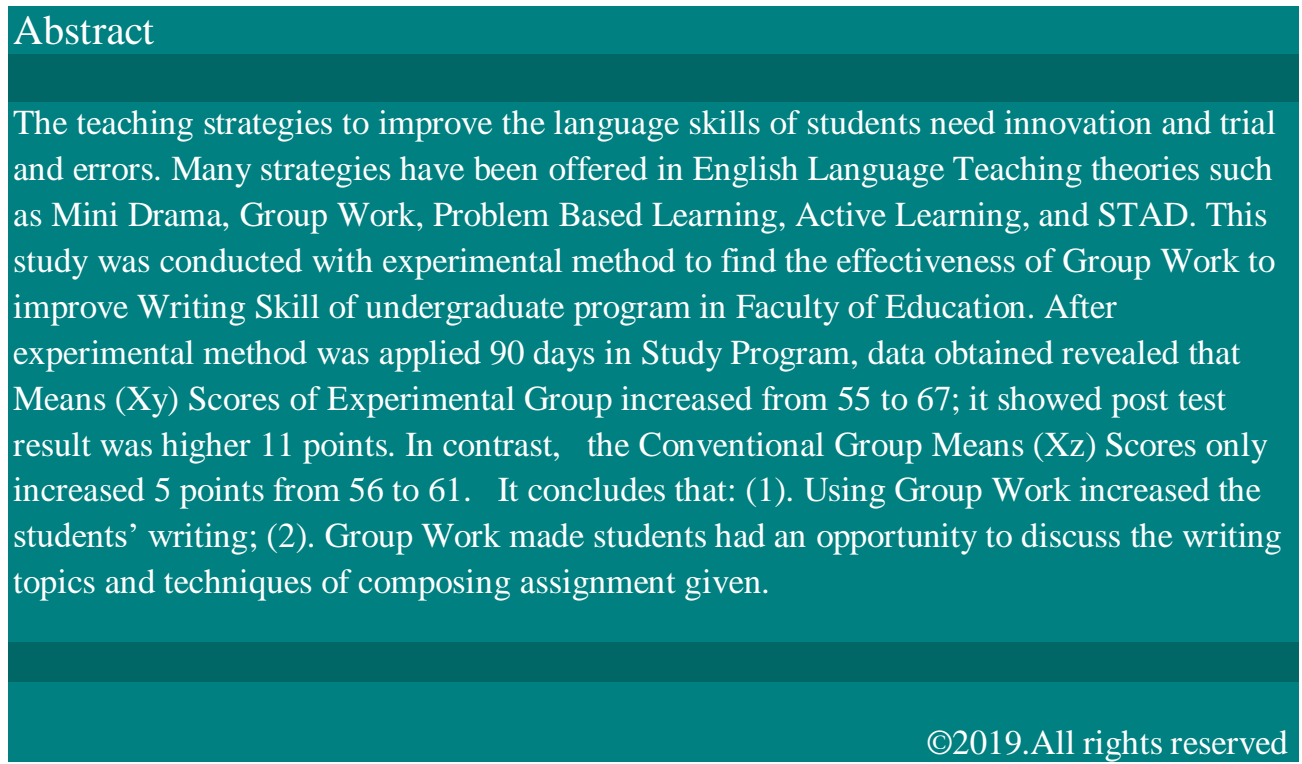

\section{ARTICLE HISTORY}

Received: 21/02/2019

Accepted: 17/06/2019

Published online: 03/10/2019

\section{KEYWORDS}

Teaching strategy, language skill, innovation, writing skill, experimental method 


\section{Introduction}

Quality of Teaching Process (Lee, 2003 and Retna \& Cavana 2013) based on the effective English Language Teaching Strategies are amied at improving the language skills of students. Writing class with low means of scores (under 60) needs teachers' innovation and studies to make the trials and errors. It notes that a few strategies have been offered in English Language Teaching theories such as Mini Drama, Group Work, Problem Based Learning, Active Learning, and STAD. For improving the language skill of undergradute students, this study was carried out with Experimental Technique to find the effectiveness of Group Work in Writing Skill.

The implementation of the language education approach in Indonesia has instructed the teachers of English as a Foreign Language (EFL) to apply the Genre -Based Approach (GBA) in English class and the teaching strategies of the English teachers which affect the effectiveness of teaching genres and text structures. The teachers of English strategies in this approach needs a comprehensive research. That Genre-Based Approach recommends teachers to developing students' abilities to use various types of English genres and texts appropriately, however they ways of teachers using genres in classrooms have not been revealed yet.

Theoretically Bathia (2002) contends that the genre in English Language Teaching incorporates a variety of frameworks applied to identify a range of textual genres. He argued that "Genre is constructed, interpreted, and used by members of various disciplinary communities in academic, professional, workplace and other institutionalised contexts(2002:12)". It is widely known that the English genres deal with formal and informal situations of communication transactions where the speakers or writers engage a single or combination of genres to propose their goals in social interactions. Bawarshi (2000) argued that "Within each genre, discourse is received in a certain mode and must receive a certain status, including even discourse endowed with an author-function (2000:2)". Teaching genre of descriptive, narrative, and argumentative makes instructors to innovate tecahing stratgies which increase the wiriting skill of students at any level of education. 
In practice in Indonesia context, it finds the English textbooks provides text studies and exercises such as narrative, recount, procedure, spoof, anecdote, and hortatory, and the structures of texts are: descriptive, narrative, exposition, and argumentative. Further, teaching materials, strategies and evaluation in Indonesia are based on the learning processes of types of English genres and texts. The contents, purposes and structures of texts are correlated with the aims of teaching English which regulated by the National Curriculum.

The problems writing class in Indonesia is low score (under 60) and some main problems are related to following aspects;

1. Students do not know how to write English texts; Students donot recognize the types of English texts.

2. Students do not recognize the way of using any procedures of writing academically.

Teaching writing skill for text types may show the convention and types English texts. For learners of English as a foreign language in Indonesia, writing within a descriptive genre in very important. Curriculum of English as a first foreign language in Indonesia recommends having students get exposed in any types of texts, so this study focuses on the Group Work in Experimental Study.

\section{Research Design}

This research uses a quasi- experimental that involves two different treatments into selected subjects. It means that the research accumulates and calculates the data found from implemented instruments. This research used an Experimental Method Design to find the effectiveness of the Group Work in Writing Class. It involved two groups of students; Control Class was treated with Conventional Teaching Strategy (in which instructor gives instruction and excersises individually). In contrast, the Experimental Group was treated through Group Assigments (in which discussion and teamwork process of writing texts administered). Treatment was made in 90 days which involved two groups; Experimental and Control. It collected data (Cox, Giesen and Green (2008) of the learning process in writing genre of descriptive, narrative and argumentative with the implementation of 
guiding texts in Experimental Group. Data analysis sought the influence of guiding texts towards the students' achievement in writing in Groupwork.

\section{Findings}

The use of GroupWork in the Experimental Class is compared to the Control one which applied the Conventional Writing Strategy. It took 90 days of implementation of GroupWork in the Experimental Class. On the other hand, the parctice of Conventional Teaching (Instructor's Center model) of Control Class also admistered in other side. Treatment was made in 90 days which involved two groups; Experimental and Control. It collected data of the learning process in writing genre of descriptive, narrative and argumentative with the implementation of guiding texts in Experimental Group The study of Group Work effectiveness in teaching Writing Skill listed as followings:

\section{Table 1}

PortFolio of Group Work of Experimental and Conventional of Control

\begin{tabular}{|c|c|c|}
\hline $\begin{array}{l}\text { Items of } \\
\text { Writings }\end{array}$ & $\begin{array}{l}\text { Group Work of } \\
\text { Experimental Group }\end{array}$ & $\begin{array}{l}\text { Conventional of } \\
\text { Control Group }\end{array}$ \\
\hline Ideas & 70 & 65 \\
\hline Structure & 78 & 68 \\
\hline Development & 75 & 68 \\
\hline Creative & 77 & 70 \\
\hline Interactive & 80 & 69 \\
\hline
\end{tabular}

Table 2 displays the better achivement of Experimental class after 90 days of admintered GroupWork in Writing lesson. It found that aIdeas in Experimental is higher 5 points, structure higher 10 points, development is higher 7 points; creative aspect is higher 7 points; interactive has 11 points from means (x) of Control Class. 
Table 2

Scores of GroupWork of Experimental Group

\begin{tabular}{|l|c|c|c|}
\hline Day & Descriptive & Narrative & Argumentative \\
\hline 1 st & 55 & 55 & 50 \\
\hline 15 th & 57 & 53 & 52 \\
\hline 30 th & 58 & 55 & 55 \\
\hline 45 th & 59 & 57 & 59 \\
\hline 60 th & 60 & 60 & 60 \\
\hline 90 th & 65 & 65 & 65 \\
\hline $\begin{array}{l}\text { Post } \\
\text { test }\end{array}$ & 76 & 65 & 63 \\
\hline
\end{tabular}

Table 2 shows the means (xy) of Scores of Experimental Groupwork in posttest is 67.It was higher 12 points from pretest achivement. It showed that Experimental Group is sucesfully to improve Writing Skill.

Table 3

\section{Scores of Conventional Teaching of Control Group}

\begin{tabular}{|c|c|c|c|}
\hline Day & Descriptive & Narrative & Argumentative \\
\hline $1 \mathrm{st}$ & 56 & 54 & 52 \\
\hline 15 th & 58 & 55 & 53 \\
\hline 30 th & 57 & 57 & 55 \\
\hline 45 th & 59 & 57 & 59 \\
\hline 60 th & 60 & 55 & 58 \\
\hline 90 th & 61 & 60 & 57 \\
\hline $\begin{array}{c}\text { Post } \\
\text { test }\end{array}$ & 63 & 61 & 59 \\
\hline
\end{tabular}

Table 3 displays that Conventional teaching means (xz) scores of Conventional Teaching of Control Group began with 56, 54, 52, and closed with $63,61,59$. It means the Conventional Teaching of Control Group means (xz) scores only improved from 56 to 61 after 90 days treatment. It contributed only 5 points. It less effective in writing class. 


\section{Discussions}

This report focuses on the influential factor in the field of English Skill; for Academic Purposes which reveals the a communicative act, generic considerations will be important in writing competence. It is in accodance with the work of Swales (1990 in Caudery, 1998) concentrates particularly on the genre of the academic paper, Naturally, the texts which derived by genres in English determine the usage of the language code such as syntax and word formation. Genres also determine the success of the text, and indeed the extent to which awareness of speakers and writers can be translated into an effective social interaction. The English teachers should create teaching strategies to practice English genres in classrooms, as what Caudery argues. He elaborates that:

Broadly speaking, Groupwork aims to group texts according to type, and to identify and describe features which texts of a particular genre have in common. The definition of the term genre varies somewhat between different writers, but most follow Swales (1990) in relating the concept of genre to communicative events or acts. In such approaches, genres are defined not in terms of their language, but by features which could be described as external to the text itself. These include areas such as text purpose, writer/reader relationships, and the medium of communication (e.g. newspaper article, letter, e-mail message). These external characteristics naturally have implications for what I will call internal features of the text, including areas such as syntax, lexical choice, organization, layout, etc. The result is that texts within a given genre are likely to share certain of these internal features, though it is also possible for texts within the same genre to differ very considerably in terms of their language and structure (Caudery, 1998)".

Teaching Writing with specific tecnique profoundly affects the ways of speakers or writers determining structures of texts that appropriate to a context of situation. Teachers are based on what they know, or what they believe, or what they believe they know, giving rise to the lack of precision in a studied genre. Table 2 displays the better achivement of Experimental class after 90 days of admintered GroupWork in Writing lesson. It found that aIdeas in Experimental is higher 5 points, structure higher 10 points, development is higher 7 points; creative aspect is higher 7 points; interactive has 11 points from means (x) of Control Class. 
Less effective teaching method results in the unsuppoted teaching condition. In that case, students are likely to have difficulty identifying which surfacelevel patterns are suitable to which genres commonly used by native speakers. Table 3 displays that Conventional teaching means (xz) scores of Conventional Teaching of Control Group began with 56, 54, 52, and closed with 63, 61, 59. It means the Conventional Teaching of Control Group means (xz) scores only improved from 56 to 61 after 90 days treatment. It contributed only 5 points. It less effective in writing class.

Building character education within writing process (Hasibuan and Matondang, 2017) is the vehicle of moral aspect in Language Education. Through which students become more acquainted with world life ; such as animals and machines, and furnishings of students' dreams and visions. Required to writing skill of a given topics, the students should ask for whom the description is meant. If a professional writer is preparing materials for a wholesale hardware magazine distributed to retailers, he or she may assume some knowledge of the object or device (Webster, 2001: 78).

\section{Conclusion}

The obtained data of the writing achievement after two treatments showed:

(a). Experimental class situation helps students in Writing lessons with the use of English as a tool for communication; genre-related factors link to the internal features of texts (Descriptive, Narrative, and Argumentative). It was faound to be more effective than teaching specific features associated with linguistics items. It provides students foundation to implement write any topics in different social environments.

(b).Less suppoted situation of learning in Conventional Teaching made the students score only grew 5 points after 90 days in Control Class. In contrast, the Experimental class made the significant increased means (XY) scores (12 points). 


\section{Disclosure statement}

No potential conflict of interest was reported by the author.

\section{Contact Information}

E-mail: saiful@ fkip.uisu.ac.id 


\section{References and notes:}

Bawarshi, A. (2000). The Genre Function. College English, Vol. 62, No. 3 (Jan., 2000), pp. $335-360$

Bhatia, V K. (2002). Applied Genre Analysis: a Multi-perspective Model, IBÉRICA 4 [2002]: pp.3-19

Caudery, Tim .(1998). Increasing students' awareness of genre through text transformation exercises: An old classroom activity revisited , The Electronic Journal for English as a Second Language; September 1998 - Volume 3, Number 3

Cox, P, Giesen, Th, and Green, R. (2008). Qualitative Reserach and Social Change: European Contexts, New York: Palragve Macmilan.

Cumming, A. 2001. Learning to Write in a Second Language: Two decades of Research. International Journal of English Studies. Vol 1/1.pp.1-23.

Hasibuan AL, \& Matondang, SA. (2017). Creative Revitalization of Classical Text for Indonesian Character Building Education, Asian Journal of Management Sciences \& Education, 6 (4), October,

Lee, A. A (2003). Quality Teaching for Diverse Students in Schooling, Best Evidence Systehesis, Wellington: Ministery of Education New Zealand.

Retna, K S And Cavana, R Y. (2013). Undergraduate Management Students'Perception of Feedback in A New Zealand University, Journal of Management \&Organization, Cambridge University Press.

Webster. (2001). Pocket Dictionary. New York: Trident Press. 